\title{
PENGARUH PEMAHAMAN STANDAR AKUNTANSI PEMERINTAH DAN PEMANFAATAN SISTEM INFORMASI AKUNTANSI TERHADAP KUALITAS LAPORAN KEUANGAN PEMERINTAH DAERAH DENGAN KOMPETENSI SDM SEBAGAI VARIABEL MODERASI (Studi Empiris Pada SKPD BPKAD Kabupaten Malang)
}

\author{
Debby Christin Sihasale \\ Email: debbychristinsihasale@gmail.com \\ Sulistyo \\ Supami Wahyu Setiyowati \\ (Program Studi Akuntansi, Fakultas Ekonomika dan Bisnis, Universitas Kanjuruhan Malang)
}

\begin{abstract}
ABSTRAK
Tujuan dari penelitian ini adalah untuk mengetahui pengaruh pemahaman standar akuntansi pemerintah (SAP) dan Pemanfaatan sistem informasi akuntansi (SIA) terhadap Kualitas laporan keuangan pemerintah daerah dengan kompetensi SDM sebagai variabel moderasi. Data yang digunakan berupa data Primer yang diperoleh melalui penyebaran kuesioner secara langsung kepada SKPD di BPKAD Kabupaten Malang. Analisis regresi yang digunakan yaitu analisis regresi berganda dengan MRA (Moderating Regression Analysis). Hasil penelitian ini menyimpulkan bahwa pemahaman SAP dan pemanfaatan SIA berpengaruh terhadap kualitas laporan keuangan pemerintah daerah, dan kompetensi sumber daya manusia mampu memoderasi (memperkuat) pengaruh pemahaman SAP dan pemanfaatan SIA terhadap kualitas laporan keuangan pemerintah daerah. Semakin tinggi kompetensi yang dimiliki aparatur pemerintah akan mendukungnya dalam memahami dan menguasai SAP dan memanfaatkan SIA dengan baik sehingga kualitas laporan keuangan menjadi semakin meningkat. Implikasinya, pemerintah harus meningkatkan pemahaman SAP dan pemanfaatan SIA agar kualitas laporan keuangan dapat meningkat, dan wajib melibatkan aparatur yang memiliki kompetensi untuk menyusun laporan keuangan agar pengaruh dari pemahaman SAP dan pemanfaatan SIA dapat meningkatkan kualitas laporan keuangan pemerintah daerah.
\end{abstract}

Kata kunci: Pemahaman SAP, Pemanfaatan SIA, Kualitas Laporan Keuangan Pemerintah Daerah, dan Kompetensi SDM

\begin{abstract}
The purpose was to determine the effect of understanding government accounting standards (SAP) and Utilization of accounting information systems (SIA) on the quality of local government financial reports with $H R$ competency as a moderating variable. The data used in the form of Primary data obtained through the distribution of questionnaires directly to the SKPD in BPKAD Malang Regency. Regression analysis used is multiple regression analysis with MRA (Moderating Regression Analysis). The results of this study concluded that the understanding of SAP and the use of SIA affect the quality of local government financial reports, and human resource competence is able to moderate (strengthen) the influence of SAP's understanding and the use of SIA on the quality of local government financial reports. The higher the competence of the government apparatus will support it in understanding and mastering SAP and making use of SIA well so that the quality of financial statements is increasingly improved. The implication is that the government must improve understanding of SAP and the use of SIA so that the quality of financial statements can improve, and it must
\end{abstract}


Debby Christin Sihasale, Pengaruh Pemahaman Standar Akuntansi Pemerintah Dan Pemanfaatan Sistem Informasi Akuntansi Terhadap Kualitas Laporan Keuangan Pemerintah Daerah Dengan Kompetensi SDM Sebagai Variabel Moderasi involve officials who have competence to prepare financial reports so that the influence of SAP's understanding and use of SIA can improve the quality of local government financial reports..

Keynotes: government accounting standards (SAP), accounting information systems (SIA), quality of local government financial reports and HR competency

\section{PENDAHULUAN}

Berlakunya kebijakan otonomi daerah yang diatur dalam Undang-undang Nomor 32 Tahun 2004 menyebabkan pemerintah harus mandiri dalam menyelenggarakan pemerintahan secara transparans dan akuntabilitas. Transparan adalah memberikan informasi dan pelayanan secara terbuka kepada publik, sedangkan akuntabilitas adalah bentuk pertanggungjawaban pemerintah atas kinerja yang telah dicapai. Transparansi dan akuntabilitas merupakan tuntutan-tuntutan yang menjadi perhatian utama bagi publik untuk memastikan apakah pengelolaan keuangan daerah sudah berjalan dengan baik. Oleh karena itu Pemerintah wajib memenuhi kedua tuntutan tersebut dengan membuat laporan pertanggungjawaban kepada publik berupa laporan keuangan (Armel, 2017).

Laporan keuangan merupakan laporan terstruktur yang digunakan untuk menyediakan Informasi yang bermanfaat bagi pengguna laporan keuangan. Segala informasi dalam laporan keuangan dapat bermanfaat jika laporan keuangan yang disajikan berkualitas sesuai dengan yang disyaratkan dalam Peraturan Pemerintah (PP) Nomor 71 Tahun 2010 tentang Standar Akuntansi Pemerintah (SAP) yaitu relevan, andal, dapat dibandingkan dan dapat dipahami (Arfianti, 2011).

SAP merupakan prinsip akuntansi dan pedoman dalam menyusun atau menyajikan laporan keuangan. Prosedur pencatatan transaksi, pembukuan sampe dengan pelaporan keuangan termuat dalam SAP (PP No. 71 Tahun 2010). Berpedoman dengan SAP dapat memudahkan aparatur bagian keuangan untuk menghasilkan laporan keuangan yang berkualitas. Penerapan SAP diyakini dapat memberikan solusi untuk setiap permasalahan keuangan yang terjadi dalam instansi pemerintah sebagai upaya untuk meningkatkan kualitas laporan keuangan pemerintah di Indonesia (Nugraheni dan Subaweh, 2008).

Penelitian tentang pemahaman SAP telah dilakukan oleh Nugraheni dan Subaweh (2008), Sari (2014), Wati (2014), Darwanis (2016), Armel (2017), Pujanira (2017), Sanjaya (2017) yang menyimpulkan bahwa pemahaman SAP berpengaruh positif terhadap kualitas laporan keuangan. Semakin baiknya pemahaman SAP maka kualitas laporan keuangan akan semakin meningkat. Sedangkan penelitian yang dilakukan oleh Artana (2016), Inapty dan Martiningsih (2016) dan Puspitawati (2016) memberikan hasil yang berbeda yaitu pemahaman SAP tidak berpengaruh terhadap kualitas laporan keuangan dikarenakan masih minimnya aparatur yang memiliki kompetensi sehingga pemahaman SAP masih belum optimal dan dikuasai oleh aparatur.

Selain pemahaman SAP, pemanfaatan sistem informasi akuntansi (SIA) juga merupakan faktor penting untuk menciptakan laporan keuangan yang berkualitas. Pemanfaatan SIA merupakan penerapan sistem mulai dari pengelompokkan, penggolongan, pencatatan, pemrosesan aktivitas keuangan pemerintah kedalam sebuah laporan keuangan untuk menghasilkan informasi yang akurat. Sehingga penting bagi setiap aparatur pemerintah untuk memanfaatkan SIA sebagaimana diamanatkan dalam Peraturan Pemerintah Nomor 56 Tahun 2005 yang kemudian direvisi menjadi Peraturan Pemerintah Nomor 65 Tahun 2010 tentang Sistem Informasi Keuangan Daerah (Sari, 2014).

Penelitian tentang variabel pemanfaatan sistem informasi akuntansi telah dilakukan oleh penelitian Yuliani (2010), Wati (2014), Silviana (2014), Purwanti (2014), Sugara (2015), Armel (2017), 
Debby Christin Sihasale, Pengaruh Pemahaman Standar Akuntansi Pemerintah Dan Pemanfaatan Sistem Informasi Akuntansi Terhadap Kualitas Laporan Keuangan Pemerintah Daerah Dengan Kompetensi SDM Sebagai Variabel Moderasi Fitriana (2017), Pujanira (2017) yang menyimpulkan bahwa pemanfaatan SIA berpengaruh terhadap kualitas laporan keuangan daerah. Semakin baik pemanfaatan SIA dalam suatu instansi maka akan meningkatkan kualitas laporan keuangan. Sedangkan penelitian yang dilakukan oleh Anggraeni (2014), Diani (2014), Pramudiarta (2015), dan Riandani (2017) memberikan hasil yang berbeda yaitu pemanfaatan SIA tidak berpengaruh terhadap kualitas laporan keuangan dikarenakan kurangnya pengetahuan aparatur dalam memanfaatkan SIA, sehingga penerapan sistem dalam Instansi pemerintah belum maksimal.

Permasalahan terkait kualitas laporan keuangan pemerintah saat ini sudah tak membaik, dikarenakan pemerintah belum sepenuhnya melakukan pembenahan-pembenahan dalam pengelolaan keuangan daerah yang mengakibatkan adanya rasa curiga dari publik kepada pemerintah mengenai kinerja pemerintah yang telah dicapai saat ini. Salah satu contohnya adalah adanya kasus suap perubahan APBD (Anggaran Pendapatan dan Belanja Daerah) tahun 2015 di Malang yang melibatkan beberapa pejabat pemerintah dan mendapat sorotan atau perhatian utama bagi publik. Penyebab kasus tersebut terjadi karena aparatur pemerintah tidak bekerja secara profesional dalam mengelola keuangan daerah sehingga pemerintah perlu melakukan pembenahan secara optimal agar kejadian serupa tidak terjadi lagi (korantransparansi.com).

Berdasarkan hasil penelitian terdahulu yang memberikan hasil tidak konsisten yang disebabkan oleh keterlibatan SDM yang tidak memiliki kompetensi dan permasalahan yang terjadi di lapangan, maka peneliti menambahkan kompetensi SDM sebagai variabel moderasi. Jogiyanto (2010) variabel moderasi merupakan variabel yang diduga memiliki hubungan kausal yang hasilnya konflik, baik konflik signifikansi maupun konflik arahnya. Kompetensi SDM digunakan sebagai variabel moderasi karena diduga dapat memperkuat hubungan antara pemahaman SAP dan pemanfaatan SIA terhadap kualitas laporan keuangan pemerintah daerah.

Tingkat kompetensi yang tinggi akan memudahkan aparatur dalam memahami dan menguasai SAP yang baik sehingga dapat mendukungya untuk mewujudkan laporan keuangan yang berkualitas (Darwanis, 2016). Teori ini diperkuat oleh penelitian Wati (2014) dan Rafid (2016) yang menyimpulkan bahwa kompetensi yang tinggi dan pemahaman SAP yang baik dapat memberikan dampak yang postif terhadap peningkatankan kualitas laporan keuangan.

Tingkat kompetensi yang tinggi dapat mempermudah aparatur pemerintah dalam memanfaatkan SIA untuk menyusun laporan keuangan sebagai upaya untuk menciptakan laporan keuangan yang berkualitas (Wati, 2014). Teori ini diperkuat oleh penelitian Sugara (2015), Agustiawan (2016), Rafid (2016) dan khairudin (2017) yang menyimpulkan bahwa kompetensi SDM yang tinggi akan mendukung dalam memanfaatan SIA dengan baik untuk menyusun laporan keuangan sehingga dapat meningkatkan kualitas laporan keuangan daerah.

Tujuan dalam penelitian ini yaitu untuk mengetahui (1) pengaruh pemahaman SAP terhadap kualitas laporan keuangan pemerintah daerah, (2) pengaruh pemanfaatan SIA terhadap kualitas laporan keuangan pemerintah daerah, (3) pengaruh kompetensi SDM sebagai variabel moderating terhadap hubungan antara pemahaman SAP dengan kualitas laporan keuangan pemerintah daerah, serta (4) pengaruh kompetensi SDM sebagai variabel moderating terhadap hubungan antara pemanfaatan SIA dengan kualitas laporan keuangan pemerintah daerah. 
Debby Christin Sihasale, Pengaruh Pemahaman Standar Akuntansi Pemerintah Dan Pemanfaatan Sistem Informasi Akuntansi Terhadap Kualitas Laporan Keuangan Pemerintah Daerah Dengan Kompetensi SDM Sebagai Variabel Moderasi

\section{TINJAUAN PUSTAKA DAN PERUMUSAN HIPOTESIS}

Stewardship theory merupakan teori yang dirancang untuk bertindak sesuai dengan keinginan principal dan berusaha untuk mencapai sasaran organisasi dengan tidak akan meninggalkan organisasinya. Manajemen pemerintah yang berperan sebagai steward atau pihak yang dipercaya akan bertindak dengan sebaik-baiknya untuk kepentingan publik (Prinsipal) karena dianggap mampu dan bertanggung jawab untuk memenuhi kebutuhan principal (para pengambil keputusan). Aparatur pemerintah yang dicerminkan sebagai Good Steward akan melaksanakan tugas dengan penuh tanggung jawab untuk menyusun laporan keuangan yang berkualitas yang dapat digunakan oleh principal untuk membuat keputusan yang rasional (Khairudin, 2017).

Standar akuntansi pemerintah (SAP) merupakan prinsip-prinsip akuntansi yang diterapkan dalam menyusun dan menyajikan laporan keuangan pemerintah (PP No. 71 Tahun 2010). SAP menjelaskan secara jelas mengenai prosedur dan aturan yang harus diperhatikan dalam menyusun laporan keuangan terkait pencatatan setiap transaksi dan pengungkapan laporan keuangan. Laporan keuangan yang berpedoman dengan SAP diyakini dapat memberikan informasi keuangan yang relevan dan andal (Rafid, 2016).

Sistem informasi akuntansi keuangan daerah didefinisikan sebagai sistem yang mampu menangani proses pengelolaan keuangan daerah mulai dari penyusunan anggaran sampai dengan pelaporan keuangan daerah. Pemanfaatan sistem informasi keuangan sangat berperan penting dalam Instansi pemerintahan untuk membantu menyusun laporan keuangan yang berkualitas (PP No. 65 Tahun 2010). Pemanfaatan sistem informasi akuntansi yang kurang maksimal dapat menimbulkan laporan keuangan menjadi kurang maksimal sehingga para pengguna tidak mendapat informasi yang bermanfaat (Hanafi, 2017).

Kualitas laporan keuangan merupakan hasil akhir dari proses kegiatan akuntansi atau ringkasan dari transaksi keuangan. laporan keuangan dapat disebut berkualitas apabila sudah memenuhi persyaratan normatif yang disyaratkan dalam Peraturan Pemerintah (PP) Nomor 71 Tahun 2010 yaitu relevan, andal, dapat dibandingkan dan dapat dipahami (Artana, 2010).

Kompetensi sumber daya manusia (SDM) merupakan kemampuan dan karakteristik yang harus dimiliki oleh pegawai untuk menjalankan tugas dan fungsinya dengan baik (PP No 101 Tahun 2000). Dalam pengelolaan keuangan daerah, kompetensi merupakan hal yang sangat penting untuk dimiliki oleh setiap aparatur dalam menyusun laporan keuangan. Aparatur yang memiliki kompetensi akan mendukungnya untuk menerapkan SAP dan memanfaatkan SIA untuk menyusun laporan keuangan yang baik dan benar (Wati, 2014).

\section{Pengaruh Pemahaman Standar Akuntansi Pemerintah Terhadap Kualitas Laporan Keuangan Pemerintah Daerah}

Tuntutan transparansi dan akuntabilitas dalam pengelolaan keuangan daerah telah menjadi sorotan publik sehingga untuk mewujudkan tuntutan tersebut pemerintah harus membuat laporan pertanggungjawaban sebagai bentuk tanggungjawab pemerintah kepada publik. Laporan pertanggungjawaban tersebut berupa laporan keuangan yang harus disusun sesuai dengan SAP sebagai upaya untuk menciptakan laporan keuangan yang berkualitas. SAP memuat proses alur penyusunan laporan keuangan pemerintah daerah secara jelas (PP No. 71 Tahun 2010). Oleh karena itu penting bagi setiap aparatur untuk dapat memahami SAP sehingga dapat membantunya untuk menerapkan SAP dalam menyusun laporan keuangan menjadi berkualitas (Khairudin, 2017). Teori 
Debby Christin Sihasale, Pengaruh Pemahaman Standar Akuntansi Pemerintah Dan Pemanfaatan Sistem Informasi Akuntansi Terhadap Kualitas Laporan Keuangan Pemerintah Daerah Dengan Kompetensi

SDM Sebagai Variabel Moderasi ini diperkuat oleh penelitian Nugraheni dan Subaweh (2008), Sari (2014), Wati (2014), Darwanis (2016), Armel (2017), Pujanira (2017), Sanjaya (2017) yang menyatakan bahwa pemahaman SAP berpengaruh positif terhadap kualitas laporan keuangan. Maka rumusan hipotesis pertama adalah:

H1 : Pemahaman SAP berpengaruh terhadap kualitas laporan keuangan pemerintah daerah

\section{Pengaruh Pemanfaatan Sistem Informasi Akuntansi Terhadap Kualitas laporan Keuangan Pemerintah Daerah}

Perkembangan teknologi informasi yang semakin berkembang menimbulkan banyak perubahan yang terjadi di kehidupan masyarakat. Salah satunya di Instansi Pemerintah yang sudah beralih menggunakan teknolgi informasi untuk menunjang aktivitasnya. Sama halnya dalam penyusunan laporan keuangan memerlukan pemanfaatan SIA untuk dapat memproses data dengan cepat dan akurat sehingga informasi keuangan dapat disajikan dengan tepat waktu dan berkualitas (Nurillah, 2014). Teori ini diperkuat oleh penelitian Yuliani (2010), Wati (2014), Silviana (2014), Purwanti (2014), Sugara (2015), Armel (2017), Fitriana (2017), Pujanira (2017) yang menyatakan bahwa pemanfaatan SIA berpengaruh signifikan terhadap kualitas laporan keuangan. Maka rumusan hipotesis kedua adalah:

H2 : Pemanfaatan SIA berpengaruh terhadap kualitas laporan keuangan pemerintah daerah.

\section{Pengaruh Kompetensi Sumber Daya Manusia Sebagai Variabel Moderasi Terhadap Hubungan} Antara Pemahaman Standar Akuntansi Dengan Kualitas Laporan Keuangan Pemerintah Daerah.

Pengelolaan keuangan daerah dapat berjalan dengan baik jika setiap aparatur pemerintah memiliki kompetensi untuk mendukung aparatur dalam menjalankan tugas dan tanggungjawabnya. Kompetensi dapat mendukung aparatur untuk memahami dan menerapkan SAP dalam menyusun laporan keuangan, karena SAP merupakan pedoman untuk menyusun dan menyajikan laporan keuangan pemerintah. Dampaknya laporan keuangan yang nanti dihasilkan menjadi berkualitas (Wati, 2014). Teori ini diperkuat oleh penelitian Wati (2014) dan Rafid (2016) yang menyimpulkan bahwa kompetensi SDM berpengaruh positif terhadap hubungan pemahaman standar akuntansi pemerintah dan kualitas laporan keuangan pemerintah daerah. Maka rumusan hipotesis ketiga adalah:

H3 : Kompetensi SDM memoderasi (memperkuat) hubungan antara pemahaman standar akuntansi pemerintah dengan kualitas laporan keuangan pemerintah daerah.

\section{Pengaruh Kompetensi Sumber Daya Sebagai Variabel Moderasi Terhadap Hubungan Antara Pemanfaatan Sistem Informasi Akuntansi Dengan Kualitas Laporan Keuangan Pemerintah Daerah}

Teknologi informasi yang semakin berkembang dapat menunjang berbagai aktivitas dan operasi dalam suatu organisasi. Pemerintah yang dulunya menggunakan sistem manual beralih menggunakan sistem informasi akuntansi berbasis komputerisasi untuk menunjang aktivitasnya. Pemanfaatan sistem informasi akuntansi dapat membantu aparatur untuk menciptakan informasi yang bermanfaat bagi para pemakai. Oleh karena itu kompetensi SDM sangat dibutuhkan dalam memanfaatkan sistem infromasi akuntansi. Jika tidak ada keterlibatan SDM yang memiliki kompetensi maka pemanfaatan sistem informasi akuntansi menjadi kurang optimal (Nuryanto dan Afiah, 2013). Teori ini diperkuat oleh penelitian Sugara (2015), Agustiawan (2016), Rafid (2016) dan khairudin (2017) yang menyimpulkan bahwa kompetensi SDM berpengaruh positif terhadap 
Debby Christin Sihasale, Pengaruh Pemahaman Standar Akuntansi Pemerintah Dan Pemanfaatan Sistem Informasi Akuntansi Terhadap Kualitas Laporan Keuangan Pemerintah Daerah Dengan Kompetensi SDM Sebagai Variabel Moderasi

hubungan pemanfaatan sistem informasi akuntansi dan kualitas laporan keuangan pemerintah daerah. Maka rumusan hipotesis keempat adalah

H4 : Kompetensi SDM memoderasi (memperkuat) hubungan antara pemanfaatan sistem informasi akuntansi dengan kualitas laporan keuangan pemerintah daerah.

\section{KERANGKA KONSEPTUAL PENELITIAN}

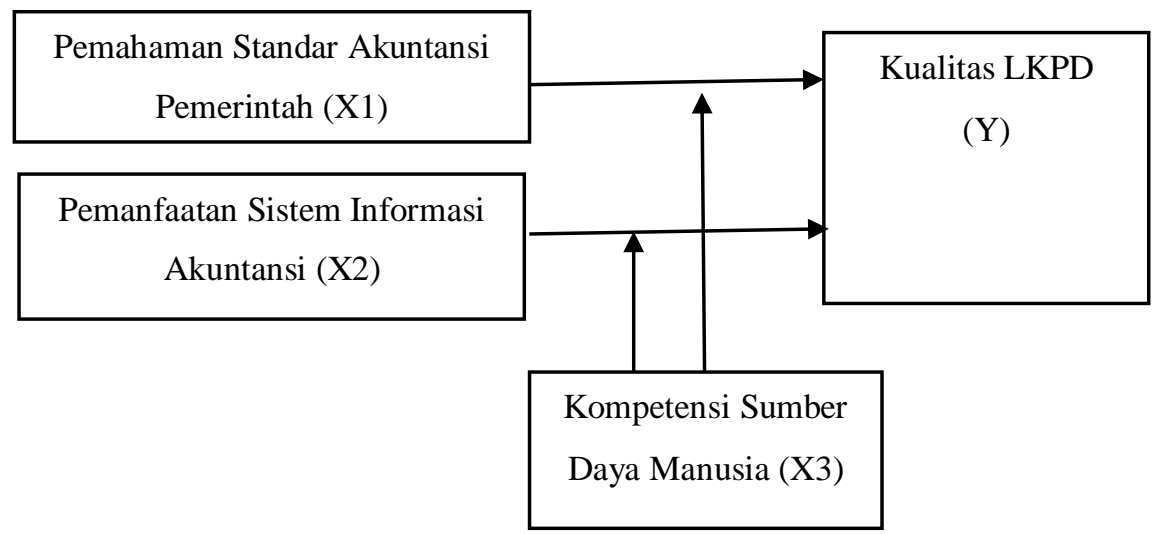

Sumber: Penelitian Terdahulu

\section{Gambar 1 Rerangka Konseptual Penelitian}

\section{METODE PENELITIAN}

Jenis penelitian yang digunakan adalah jenis penelitian konklusif atau penelitian kausal (Casual research) merupakan tipe penelitian dengan karakteristik permasalahan berubah hubungan sebab akibat antara dua variabel atau lebih (Sugiyono, 2011). Populasi dalam penelitian ini adalah SKPD yang bekerja di Badan Pengelola Keuangan Dan Aset Daerah (BPKAD) Kabupaten Malang. Sampel penelitian ini adalah kepala Dinas, Sekretaris, Bendahara dan Staf Keuangan pada Kantor BPKAD Kabupaten Malang. Teknik pengambilan sampel dengan menggunakan purposive sampling. Kriteria dalam pengambilan sampel ini adalah:

a. Pegawai yang bekerja (SKPD) di BPKAD Kabupaten Malang

b. Memiliki masa kerja menimal 1 tahun

c. Menjabat sebaga Kepala Dinas, Sekretaris, Bendahara, dan Staf Keuangan

Penelitian ini menggunakan data kuantitatif, bentuk data kuantitatif dalam penelitian ini adalah berupa nilai atau skor atas jawaban yang diberikan oleh responden terhadap pertanyaan-pertanyaan yang diajukan peneliti dalam kuesioner. Sedangkan sumber data yang digunakan pada penelitian ini adalah data primer Teknik pengumpulan data dilakukan dengan cara penyebaran kuesioner secara langsung kepada responden tanpa adanya perantara.

\section{Definisi opersional dan pengukuran variabel}

Variabel dependen (terikat) merupakan variabel yang dipengaruhi atau yang menjadi akibat karena adanya variabel bebas (Sugiyono, 2011). Variabel dependen dalam penelitian ini adalah kualitas laporan keuangan pemerintah daerah. Kualitas laporan keuangan merupakan hasil akhir dari kegiatan akuntansi atau ringkasan dari transaksi keuangan (Artana, 2016). 
Debby Christin Sihasale, Pengaruh Pemahaman Standar Akuntansi Pemerintah Dan Pemanfaatan Sistem Informasi Akuntansi Terhadap Kualitas Laporan Keuangan Pemerintah Daerah Dengan Kompetensi SDM Sebagai Variabel Moderasi

Variabel independen merupakan variabel yang mempengaruhi atau menjadi sebab perubahannya atau timbulnya variabel dependen (Sugiyono, 2011). Variabel dependen dalam penelitian ini adalah Pemahaman standar akuntansi pemerintah (SAP) dan pemanfaatan sistem informasi akuntansi (SIA). Pemahaman SAP merupakan prinsip atau pedoman akuntansi yang harus dipahami oleh seorang aparatur dalam menyusun laporan keuangan pemerintah (Rafid, 2016). Sedangkan Pemanfaatan SIA merupakan penerapan sistem yang telah dimanfaatkan untuk menunjang aktivitas pemerintah dalam menyusun laporan keuangan agar dapat menghasilkan informasi keuangan yang akurat dan tepat waktu (Sari, 2014).

Varibel moderasi merupakan variabel yang memperkuat atau memperlemah hubungan langsung antara variable independen dengan variabel dependen (Sugiyono, 2011). Variabel moderasi dalam penelitian ini adalah kompetensi SDM. Kompetensi SDM merupakan kemampuan dasar seseorang untuk mencapai kinerja yang tinggi dalam menyelesaikan tugas dan tanggungjawabnya (Wati, 2014).

Tabel 1 Pengukuran Variabel

\begin{tabular}{|c|c|c|}
\hline Variabel & Indikator & Skala Pengukuran \\
\hline $\begin{array}{l}\text { Kualitas Laporan Keuangan } \\
\text { Pemerintah Daerah }(\mathrm{Y})\end{array}$ & $\begin{array}{l}\text { Berdasarkan Peraturan Pemerintah Nomor } \\
71 \text { Tahun } 2010 \text { persyaratan normatif kualitas } \\
\text { laporan keuangan: } \\
\text { 1. Relevan } \\
\text { 2. Andal } \\
\text { 3. Dapat dibandingkan } \\
\text { 4. Dapat dipahami }\end{array}$ & Interval (Likert) \\
\hline $\begin{array}{l}\text { Pemahaman Standar Akuntansi } \\
\text { Pemerintah (X1) }\end{array}$ & 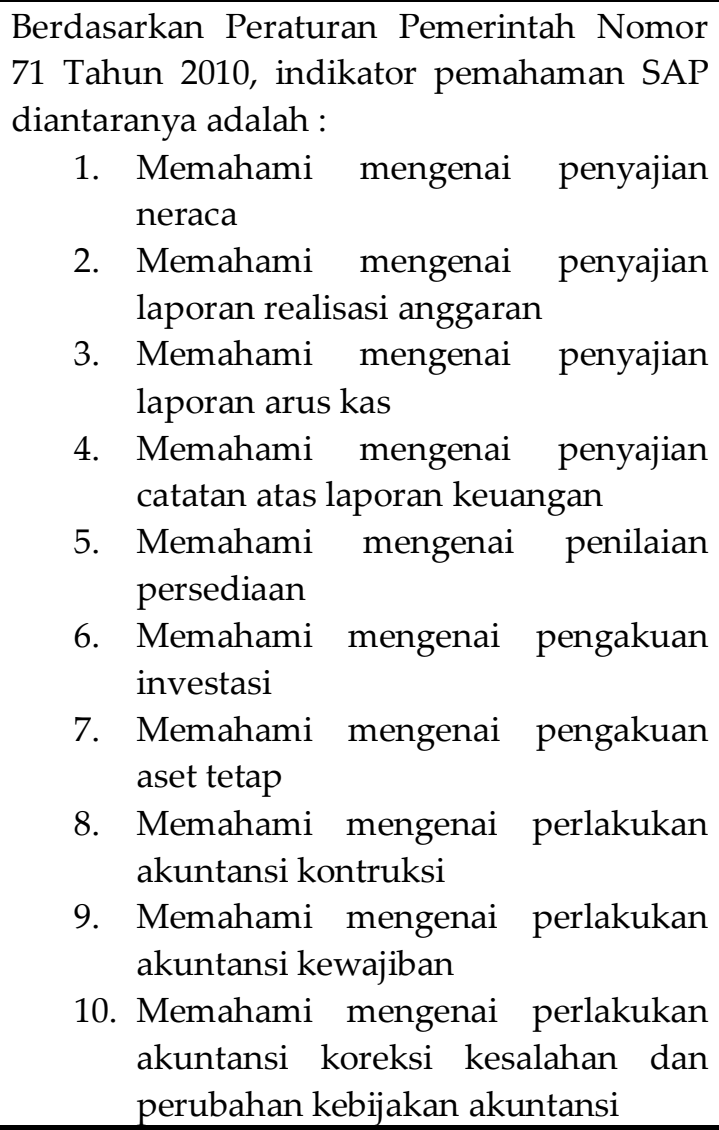 & Interval (Likert) \\
\hline Pemanfaatan Sistem Informasi & Berdasarkan indikator Wikison et al (2000) & Interval (Likert) \\
\hline
\end{tabular}


Debby Christin Sihasale, Pengaruh Pemahaman Standar Akuntansi Pemerintah Dan Pemanfaatan Sistem Informasi Akuntansi Terhadap Kualitas Laporan Keuangan Pemerintah Daerah Dengan Kompetensi SDM Sebagai Variabel Moderasi

\begin{tabular}{|c|c|c|}
\hline Akuntansi (X2) & $\begin{array}{l}\text { dalam Rafid (2016) yaitu: } \\
\text { 1. Sistem akuntansi sesuai dengan SAP } \\
\text { 2. Jaringan internet berkualitas } \\
\text { 3. Jaringan internet termanfaat dengan } \\
\text { baik } \\
\text { 4. Aplikasi yang digunakan } \\
\text { bermanfaat } \\
\text { 5. Laporan keuangan terkomputerisasi } \\
\text { 6. Software sesuai dengan Undang- } \\
\text { undang }\end{array}$ & \\
\hline $\begin{array}{lll}\text { Kompetensi } & \text { Sumber } & \text { Daya } \\
\text { Manusia }(X 3) & & \end{array}$ & $\begin{array}{l}\text { Berdasarkan indikator dari Xu et al (2003) } \\
\text { dalam Rafid (2016) yaitu: } \\
\text { 1. Pemahaman tentang akuntansi } \\
\text { 2. SDM yang berkualitas } \\
\text { 3. SDM yang memadai } \\
\text { 4. Peran dan tanggungjawab } \\
\text { 5. Pelatihan keahlian dalam tugas } \\
\text { 6. Sosialisasi peraturan baru }\end{array}$ & Interval (Likert) \\
\hline
\end{tabular}

Sumber: Data diolah dari beberapa referensi jurnal, 2018

\section{Teknik analisis data}

1. Pengujian Kualitas Data

Uji Validitas

Uji validitas bertujuan untuk mengukur sah atau valid tidaknya suatu kuesioner. Data dapat dinyatakan valid jika $\mathrm{r}$ hitung yang merupakan nilai dari corrected item-total correlation lebih besar dari $\mathrm{r}$ tabel pada signifikan 0,05 atau 5\% (Sugiyono, 2011).

Uji Reliabilitas

Uji reliabilitas bertujuan untuk mengukur tingkat keterandalan dari instrument yang digunakan. Syarat minimum yang dianggap memenuhi kriteria atau dianggap reliable adalah jika nilai koefisien alpha cronbach's yang didapat adalah o,6 atau lebih dari 0,6 (Sugiyono, 2011).

2. Pengujian Asumsi Klasik

\section{Uji Autokerelasi}

Uji autokorelasi bertujuan untuk mengetahui korelasi antara kesalahan variabel penganggu pada periode $\mathrm{t}$ (sekarang) dengan periode $\mathrm{t}-1$ (sebelumnya) dengan model regresi yng digunakan. Penelitian ini menggunakan pendekatan Durbin-Watson untuk mendeteksi autokeralsi dengan kriteria $\mathrm{DU}<\mathrm{DW}<4$-DU maka data dapat dinyatakan tidak terjadi autokorelasi.

\section{Uji Normalitas}

Uji normalitas bertujuan untuk menguji apakah model regresi, variabel penganggu (residual) memiliki distribusi normal atau tidak. Uji normalitas dalam penelitian ini menggunakan Kolmogrov-Smirnov dengan melihat signifikansi (Asymp. Sign) harus lebih besar dari 0,05 atau 5\%, maka data dapat dinyatakan berditribusi normal (Ghozali, 2012). 
Debby Christin Sihasale, Pengaruh Pemahaman Standar Akuntansi Pemerintah Dan Pemanfaatan Sistem Informasi Akuntansi Terhadap Kualitas Laporan Keuangan Pemerintah Daerah Dengan Kompetensi SDM Sebagai Variabel Moderasi

\section{Uji Multikolinearitas}

Uji multikolinearitas bertujuan untuk menguji apakah model regresi ditemukan adanya korelasi antar variabel bebas. Kriteria dalam pengujian ini adalah dengan melihat nilai tolerance $>0,1$ atau VIF (variance inflation factor) $<10$ maka data dapat dinyatakan tidak terjadi multikolinearitas (Ghozali, 2012).

Uji Heteroskedastisitas

Uji heteroskedastisitas bertujuan untuk menguji apakah model regresi yang digunakan ada ketidaksamaan atas variance dari residual suatu pengamatan ke pengamatan yang lain. Uji heteroskedastisitas dapat dilakukan dengan uji Glejser dengan kriteria nilai sgnifikansi lebih besar dari 0,05 atau 5\% dapat dinyatakan data tidak terjadi heteroskedastisitas (Ghozali, 2012).

3. Analisis Regresi

Analisis regresi yang digunakan dalam penelitian ini adalah analisis regresi linier berganda dengan Moderate Regression Analysis (MRA). Analisis regresi linear berganda dengan MRA merupakan model regresi yang mengandung unsur interaksi yaitu perkalian dua atau lebih variabel independen untuk mengansumsikan adanya hubungan antara variabel dependen dengan variabel independen dan variabel moderasi (Ghozali, 2012). Persamaan regresi dengan MRA dapat dirumuskan sebagai berikut:

\begin{tabular}{ll|}
\hline \multicolumn{1}{|c|}{$\mathbf{Y}=\boldsymbol{\alpha}+\boldsymbol{\beta}_{1} \mathbf{X}_{1}+\boldsymbol{\beta}_{\mathbf{2}} \mathbf{X}_{\mathbf{2}}+\boldsymbol{\beta}_{3} \mathbf{X}_{\mathbf{3}}+\boldsymbol{\beta}_{\mathbf{4}} \mathbf{X}_{1} \mathbf{X}_{\mathbf{3}}+\boldsymbol{\beta}_{5} \mathbf{X}_{\mathbf{2}} \mathbf{X}_{\mathbf{3}}+\mathbf{e}$} \\
\hline Keterangan: \\
$\alpha \quad:$ Konstanta \\
$\beta 1-\beta 5$ & $:$ Koefisien Regresi \\
$\mathrm{e}$ & $:$ Error \\
X1 & : Pemahaman standar akuntansi pemerintah (SAP) \\
X2 & $:$ Pemanfaatan sistem informasi akuntansi (SIA) \\
X3 & $:$ Kompetensi sumber daya manusia (SDM) \\
X1X3 & $:$ Interaksi antara X1 dan X3 (Pemahaman SAP dan Kompetensi SDM) \\
X2X3 & $:$ Interaksi antara X2 dan X3 (Pemanfaatan SIA dan Kompetensi SDM)
\end{tabular}

4. Pengujian Hipotesis

Pengujian hipotesis menggunakan regresi linear berganda dengan MRA. Pengujian ini bertujuan untuk menguji apakah variabel independen yaitu pemahaman SAP dan pemanfaatan SIA berpengaruh terhadap variabel dependen yaitu kualitas laporan keuangan pemerintah daerah dan untuk menguji apakah variabel moderasi yaitu kompetensi SDM dapat memperkuat atau memperlemah hubungan variabel independen (pemahaman SAP dan pemanfaatan SIA) dengan variabel dependen (kualitas laporan keuangan pemerintah daerah). hipotesis pertama, kedua, ketiga dan keempat menggunakan uji parsial (Uji t) dengan kriteria jika nilai alpha $<0,05$ dan nilai $t$ hitung $>t$ tabel maka Hipotesis diterima. Sebaliknya, jika nilai alpha $>0,05$ nilai $t$ hitung $<t$ tabel maka hipotesis ditolak (Ghozali, 2012).

\section{HASIL PENELITIAN}

\section{Deskripsi Data}

Peneliti menyebar kuesioner sebanyak 50 rangkap kuesioner kepada SKPD di BPKAD Kabupaten Malang. Kuesioner yang kembali dan yang dapat diolah akan dijelaskan pada tabel ringkasan pengiriman dan pengembalian kueisoner dibawah ini: 
Debby Christin Sihasale, Pengaruh Pemahaman Standar Akuntansi Pemerintah Dan Pemanfaatan Sistem Informasi Akuntansi Terhadap Kualitas Laporan Keuangan Pemerintah Daerah Dengan Kompetensi SDM Sebagai Variabel Moderasi

Tabel 2 Ringkasan pengiriman dan pengembalian kuesioner

\begin{tabular}{|l|c|c|}
\hline \multicolumn{1}{|c|}{ Keterangan } & Jumlah & Persentase (\%) \\
\hline Kuesiner yang tidak kembali & 10 & $20 \%$ \\
\hline Kuesioner yang dapat diolah & 35 & $70 \%$ \\
\hline Kuesioner yang tidak dapat diolah & 5 & $10 \%$ \\
\hline Jumlah kuesioner yang disebar & 50 & $100 \%$ \\
\hline
\end{tabular}

Sumber: Data primer diolah, 2018

\section{Uji Kualitas Data}

\section{Validitas}

Nilai $r$ tabel pada penelitian ini dengan jumlah sampel sebanyak 35 adalah 0,334. Hasil uji validitas pada penelitian ini akan disajikan pada tabel 3 berikut:

Tabel 3 Variabel X1 (Pemahaman standar akuntansi pemerintah)

\begin{tabular}{|l|c|c|c|c|}
\hline \multicolumn{1}{|c|}{$\begin{array}{c}\text { Item } \\
\text { Pertanyaan }\end{array}$} & $\begin{array}{c}\text { Corrected item- } \\
\text { total correlation } \\
\text { (R hitung) }\end{array}$ & signifikansi & R tabel & Kesimpulan \\
\hline X1.1 & 0,913 & 0,000 & 0,334 & Valid \\
\hline X1.2 & 0,998 & 0,000 & 0,334 & Valid \\
\hline X1.3 & 0,908 & 0,000 & 0,334 & Valid \\
\hline X1.4 & 0,977 & 0,000 & 0,334 & Valid \\
\hline X1.5 & 0,906 & 0,000 & 0,334 & Valid \\
\hline X1.6 & 0,998 & 0,000 & 0,334 & Valid \\
\hline X1.7 & 0,975 & 0,000 & 0,334 & Valid \\
\hline X1.8 & 0,974 & 0,000 & 0,334 & Valid \\
\hline X1.9 & 0,917 & 0,000 & 0,334 & Valid \\
\hline X1.10 & 0,925 & 0,000 & 0,334 & Valid \\
\hline
\end{tabular}

Sumber: Hasil pengolahan data 2018

Variabel X2 (Pemanfaatan sistem informasi akuntansi

\begin{tabular}{|l|c|c|c|c|}
\hline \multicolumn{1}{|c|}{$\begin{array}{c}\text { Item } \\
\text { Pertanyaan }\end{array}$} & $\begin{array}{c}\text { Corrected item- } \\
\text { total correlation } \\
\text { (R hitung) }\end{array}$ & signifikansi & R tabel & Kesimpulan \\
\hline X2.1 & 0,935 & 0,000 & 0,334 & Valid \\
\hline X2.2 & 0,969 & 0,000 & 0,334 & Valid \\
\hline X2.3 & 0,921 & 0,000 & 0,334 & Valid \\
\hline X2.4 & 0,933 & 0,000 & 0,334 & Valid \\
\hline X2.5 & 0,914 & 0,000 & 0,334 & Valid \\
\hline X2.6 & 0,884 & 0,000 & 0,334 & Valid \\
\hline
\end{tabular}

Sumber: Hasil pengolahan data 2018

Variabel X3 (Kompetensi sumber daya manusia)

\begin{tabular}{|l|c|c|c|c|}
\hline \multicolumn{1}{|c|}{ Item } & $\begin{array}{c}\text { Corrected item- } \\
\text { total correlation } \\
\text { (R hitung) }\end{array}$ & signifikansi & R tabel & Kesimpulan \\
\hline X3.1 & 0,849 & 0,000 & 0,334 & Valid \\
\hline X3.2 & 0,902 & 0,000 & 0,334 & Valid \\
\hline X3.3 & 0,942 & 0,000 & 0,334 & Valid \\
\hline
\end{tabular}


Debby Christin Sihasale, Pengaruh Pemahaman Standar Akuntansi Pemerintah Dan Pemanfaatan Sistem Informasi Akuntansi Terhadap Kualitas Laporan Keuangan Pemerintah Daerah Dengan Kompetensi SDM Sebagai Variabel Moderasi

\begin{tabular}{|l|l|l|l|l|}
\hline X3.4 & 0,862 & 0,000 & 0,334 & Valid \\
\hline X3.5 & 0,914 & 0,000 & 0,334 & Valid \\
\hline X3.6 & 0,800 & 0,000 & 0,334 & Valid \\
\hline
\end{tabular}

Sumber: Hasil pengolahan data 2018

Variabel Y (Kualitas laporan keuangan pemerintah daerah)

\begin{tabular}{|l|c|c|c|c|}
\hline $\begin{array}{c}\text { Item } \\
\text { Pertanyaan }\end{array}$ & $\begin{array}{c}\text { Corrected item- } \\
\text { total correlation } \\
\text { (R hitung) }\end{array}$ & signifikansi & Resimpulan \\
\hline Y1 & 0,591 & 0,000 & 0,334 & Valid \\
\hline Y2 & 0,725 & 0,000 & 0,334 & Valid \\
\hline Y3 & 0,785 & 0,000 & 0,334 & Valid \\
\hline Y4 & 0,735 & 0,000 & 0,334 & Valid \\
\hline Y5 & 0,664 & 0,000 & 0,334 & Valid \\
\hline Y6 & 0,632 & 0,000 & 0,334 & Valid \\
\hline Y7 & 0,583 & 0,000 & 0,334 & Valid \\
\hline Y8 & 0,686 & 0,000 & 0,334 & Valid \\
\hline
\end{tabular}

Sumber: Hasil pengolahan data 2018

\section{Reliabilitas}

Hasil uji reliabilitas dengan pendekatan Nilai Cronbach's Alpha akan disajikan pada tabel 4 berikut:

Tabel 4 Hasil Uji Reliabilitas

\begin{tabular}{|l|c|c|c|}
\hline \multicolumn{1}{|c|}{ Variabel } & Cronbach's Alpha & Standar Reliabilitas & Kesimpulam \\
\hline Pemahaman SAP (X1) & 0,987 & 0,60 & Reliabel \\
\hline Pemanfaatan SIA (X2) & 0,966 & 0,60 & Reliabel \\
\hline Kompetensi SDM (X3) & 0,939 & 0,60 & Reliabel \\
\hline $\begin{array}{l}\text { Kualitas laporan keuangan } \\
\text { pemerintah daerah (Y) }\end{array}$ & 0,827 & 0,60 & Reliabel \\
\hline
\end{tabular}

Sumber: Hasil pengolahan data, 2018

\section{Uji Asumsi Klasik}

Hasil uji asumsi klasik dalam penelitian ini akan disajikan pada tabel 5 berikut:

Tabel 5 Hasil Uji Asumsi Klasik

\begin{tabular}{|l|c|c|c|c|c|}
\hline Variabel Bebas & VIF & Kriteria & Signifikan & Kriteria & Kesimpulan \\
\hline $\begin{array}{l}\text { Pemahaman } \\
\text { SAP }(X 1)\end{array}$ & 6.456 & $<10$ & 0,318 & $>0,05$ & $\begin{array}{c}\text { Tidak terjadi multikolinearitas dan } \\
\text { heteroskedastisitas }\end{array}$ \\
\hline $\begin{array}{l}\text { Pemanfaatan } \\
\text { SIA (X2) }\end{array}$ & 8.580 & $<10$ & 0,189 & $>0,05$ & $\begin{array}{r}\text { Tidak terjadi multikolinearitas dan } \\
\text { heteroskedastisitas }\end{array}$ \\
\hline $\begin{array}{l}\text { Kompetensi } \\
\text { SDM (X3) }\end{array}$ & 9.689 & $<10$ & 0,418 & $>0,05$ & $\begin{array}{l}\text { Tidak terjadi multikolinearitas dan } \\
\text { heteroskedastisitas }\end{array}$ \\
\hline $\begin{array}{l}\text { Pemahaman } \\
\text { SAP*Kompetensi } \\
\text { SDM (X1X3) }\end{array}$ & 9.728 & $<10$ & 0,263 & $>0,05$ & $\begin{array}{l}\text { Tidak terjadi multikolinearitas dan } \\
\text { heteroskedastisitas }\end{array}$ \\
\hline Pemanfaatan & 9.963 & $<10$ & 0,109 & $>0,05$ & Tidak terjadi multikolinearitas dan \\
\hline
\end{tabular}


Debby Christin Sihasale, Pengaruh Pemahaman Standar Akuntansi Pemerintah Dan Pemanfaatan Sistem Informasi Akuntansi Terhadap Kualitas Laporan Keuangan Pemerintah Daerah Dengan Kompetensi SDM Sebagai Variabel Moderasi

\begin{tabular}{|l|l|l|l|l|}
\hline $\begin{array}{l}\text { SIA*Kompetensi } \\
\text { SDM }(\mathrm{X} 2 \mathrm{X3})\end{array}$ & & & & heteroskedastisitas \\
\hline Durbin-Watson $=1.905$ & $>0,05$ & Tidak terjadi autokorelasi \\
\hline Asymp.Sign $=0,826$ & Terdistribusi normal \\
\hline
\end{tabular}

Sumber: Hasil pengolahan data, 2018

Analisis Regresi

Hasil analisis regresi akan disajikan pada tabel 6 berikut:

Tabel 6 Analisis Regresi Moderasian

\begin{tabular}{|l|c|c|c|}
\hline \multicolumn{1}{|c|}{ Variabel } & \multicolumn{1}{|c|}{$\begin{array}{c}\text { Unstandardized } \\
\text { Coefficients }\end{array}$} & Nilai Sig. & Kesimpulan \\
\hline Pemahaman SAP (X1) & $-0,217$ & 0,015 & Berpengaruh \\
\hline Pemanfaatan SIA (X2) & 0,244 & 0,050 & Berpengaruh \\
\hline Kompetensi SDM (X3) & $-0,601$ & 0,000 & Berpengaruh \\
\hline $\begin{array}{l}\text { Pemahaman SAP dan Kompetensi } \\
\text { SDM (X1X3) }\end{array}$ & 0,015 & $\begin{array}{c}\text { Memoderasi } \\
\text { (memperkuat) }\end{array}$ \\
\hline $\begin{array}{l}\text { Pemanfaatan SIA dan Kompetensi } \\
\text { SDM }(\mathrm{X} 2 \mathrm{X} 3)\end{array}$ & 0,048 & $\begin{array}{c}\text { Memoderasi } \\
\text { (memperkuat) }\end{array}$ \\
\hline $\begin{array}{l}\text { Nilai signifikansi }=0,000 \\
\mathrm{R} \text { square }=0,833\end{array}$ & 012 & \\
\hline $\begin{array}{l}\text { Model regresi yang diperoleh sebagai berikut: } \\
\mathrm{Y}=\alpha+\beta_{1} \mathrm{X}_{1}+\beta_{2} \mathrm{X}_{2}+\beta_{3} \mathrm{X}_{3}+\beta_{4} \mathrm{X}_{1} \mathrm{X}_{3}+\beta_{5} \mathrm{X}_{2} \mathrm{X}_{3}+\mathrm{e} \\
\mathrm{Y}=34.274-0,217 \mathrm{X}_{1}+0,244 \mathrm{X}_{2}-0,601 \mathrm{X}_{3}+0,015 \mathrm{X}_{1} \mathrm{X}_{3}+0,012 \mathrm{X}_{2} \mathrm{X}_{3}+\mathrm{e}\end{array}$ \\
\hline
\end{tabular}

Sumber: output SPSS 16 (data diolah peneliti, 2018)

Berdasarkan pada persamaan regresi diatas dapat dijelaskan sebagai berikut:

1) Nilai konstansta sebesar 32.274 memiliki arti apabila variabel lainnya konstan, maka nilai kualitas laporan keuangan pemerintah daerah sebesar 32.274

2) Nilai koefisien regresi pemahaman SAP bertanda negatif 0,217 . Artinya jika pemahaman SAP terjadi kenaikan sebesar 1 satuan dengan asumsi variabel lainnya konstan, maka kualitas keuangan pemerintah daerah akan menurun sebesar 0,217\%

3) Nilai koefisien regresi pemanfaatan SIA bertanda positif 0,244. Artinya jika pemanfaatan SIA terjadi kenaikan 1 satuan dengan asumsi variabel lainya konstan, maka kualitas laporan keuangan pemerintah daerah akan naik sebesar $0,244 \%$

4) Nilai koefisien regresi kompetensi SDM bertanda negatif 0,601. Artinya jika kompetensi SDM terjadi kenaikan sebesar 1 satuan dengan asumsi variabel lainnya konstan, maka kualitas laporan keuangan pemerintah daerah akan menurun sebesar 0,601\%

5) Nilai koefisien regresi interaksi variabel pemahaman SAP dan kompetensi SDM bertanda positif 0,015. Artinya jika interaksi variabel pemahaman SAP dan kompetensi SDM terjadi kenaikan 1 satuan, maka kualitas laporan keuangan pemerintah daerah akan naik sebesar $0,015 \%$

6) Nilai koefisien regresi interaksi variabel pemanfaatan SIA dan kompetensi SDM bertanda positif 0,012. Artinya jika interaksi variabel pemanfaatan SIA dan kompetensi SDM terjadi kenaikan 1 satuan, maka kualitas laporan keuangan akan naik sebesar $0,012 \%$.

7) Nilai R square sebesar 0,833 atau $83.3 \%$ mengindikasikan bahwa naik atau turunnya kualitas laporan keuangan pemerintah daerah dipengaruhi oleh pamahaman SAP dan pemanfaatan SIA yang dimoderasi oleh kompetensi SDM. Sedangkan 16,7\% dipengaruhi oleh variabel-variabel lain yang tidak digunakan dalam penelitian ini. 
Debby Christin Sihasale, Pengaruh Pemahaman Standar Akuntansi Pemerintah Dan Pemanfaatan Sistem Informasi Akuntansi Terhadap Kualitas Laporan Keuangan Pemerintah Daerah Dengan Kompetensi SDM Sebagai Variabel Moderasi

\section{Hasil Uji Hipotesis}

H1: Pengaruh Pemahaman Standar Akuntansi Pemerintah terhadap Kualitas Laporan Keuangan Pemerintah Daerah

Nilai signifikansi variabel pemahaman SAP $X_{1}==\Rightarrow$ Y sebesar 0,015 $<0,05(5 \%)$ dan nilai thitung $-2.579>\mathrm{t}$ tabel 2.030 berarti pemahaman SAP berpengaruh terhadap Kualitas laporan keuangan pemerintah daerah, karena koefisien regresi menunjukkan angka yang negatif, maka dapat disimpulkan bahwa pemahaman SAP berpengaruh negatif terhadap kualitas laporan keuangan pemerintah daerah sehingga hipotesis pertama $\left(\mathrm{H}_{1}\right)$ diterima.

\section{$\mathrm{H}_{2}$ : Pengaruh Pemanfaatan SIA terhadap Kualitas Laporan Keuangan Pemerintah Daerah}

Nilai signifikansi variabel pemanfaatan SIA $X_{2}=>$ Y sebesar 0,050 sama dengan alpa 0,05 (5\%) dan nilai t hitung $2.043>\mathrm{t}$ tabel 2.030, berarti pemanfaatan SIA berpengaruh terhadap kualitas laporan keuangan pemerintah daerah. Karena koefisien regresi menunjukkan angka yang positif maka dapat disimpulkan pemanfaatan SIA berpengaruh positif terhadap kualitas laporan keuangan pemerintah daerah. Sehingga hipotesis kedua $\left(\mathrm{H}_{2}\right)$ diterima.

$\mathrm{H}_{3}$ : Pengaruh kompetensi SDM sebagai Variabel Moderating terhadap Hubungan antara Pemahaman SAP dengan Kualitas Laporan Keuangan Pemerintah Daerah

Nilai signifikansi variabel moderating $X_{1} X_{3}==\Rightarrow Y$ sebesar $0,001<0,05(5 \%)$ dan nilai $t$ hitung $3.755>t$ tabel 2.030, berarti kompetensi SDM mampu memoderasi hubungan antara pemahaman SAP dengan kualitas laporan keuangan pemerintah daerah. Karena koefisien regresi menunjukkan angka yang positif, maka dapat disimpulkan kompetensi SDM memoderasi (memperkuat) hubungan antara pemahaman SAP dengan kualitas laporan keuangan pemerintah daerah. Sehingga hipotesis ketiga $\left(\mathrm{H}_{3}\right)$ diterima.

H4: Pengaruh Kompetensi SDM sebagai Variabel Moderating terhadap Hubungan antara Pemanfaatan SIA dengan Kualitas Laporan Keuangan Pemerintah Daerah

Nilai signifikansi variabel moderating $X_{2} X_{3}==>$ Y sebesar $0,048<0,05(5 \%)$ dan nilai t hitung $2.061>t$ tabel 2.030, berarti kompetensi SDM mampu memoderasi hubungan antara pemanfaatan SIA dengan kualitas laporan keuangan pemerintah daerah. Karena koefisien regresi menunjukkan angka yang positif, maka dapat disimpulkan kompetensi SDM memoderasi (memperkuat) hubungan antara pemanfaatan SIA dengan kualitas laporan keuangan pemerintah daerah. Sehingga hipotesis keempat $\left(\mathrm{H}_{4}\right)$ diterima.

\section{PEMBAHASAN}

Pengaruh Pemahaman SAP terhadap Kualitas Laporan Keuangan Pemerintah Daerah

Pemahaman SAP berpengaruh terhadap kualitas laporan keuangan. Kurangnya pemahaman SAP yang dimiliki oleh pegawai akan berdampak pada kualitas laporan keuangan pemerintah daerah semakin menurun. Sebaliknya banyaknya pemahaman SAP yang dimiliki pegawai akan berdampak pada kualitas laporan keuangan pemerintah daerah semakin meningkat. Teori stewardsip menyatakan bahwa pemerintah sebagai steward akan bertindak sebaik mungkin untuk memenuhi kepentingan publik bukan kepentingan sendiri. Pemerintah akan berusaha menjalankan tugas dan fungsinya dengan penuh tanggung jawab. Salah satu tugas pemerintah adalah membuat laporan keuangan yang berkualitas. Laporan keuangan akan berkualitas jika disusun sesuai dengan SAP (PP 
Debby Christin Sihasale, Pengaruh Pemahaman Standar Akuntansi Pemerintah Dan Pemanfaatan Sistem Informasi Akuntansi Terhadap Kualitas Laporan Keuangan Pemerintah Daerah Dengan Kompetensi SDM Sebagai Variabel Moderasi No. 71 Tahun 2010). Oleh karena itu pemerintah akan mewajibkan pegawainya untuk memahami dengan baik mengenai SAP yang dijadikan pedoman dalam menyusun laporan keuangan, sehingga mereka dapat menyajikan laporan keuangan yang baik dan benar sesuai dengan SAP (Khairudin, 2017). Hasil penelitian ini diperkuat oleh Nugraheni dan Subaweh (2008), Sari (2014), Darwanis (2016), Armel (2017), Pujanira (2017), Sanjaya (2017), dan bertentangan dengan penelitian Artana (2016), Inapty dan Martiningsih (2016) dan Puspitawati (2016).

\section{Pengaruh Pemanfaatan SIA terhadap Kualitas Laporan Keuangan Pemerintah Daerah}

Pemanfaatan SIA berpengaruh terhadap kualitas laporan keuangan pemerintah daerah. Semakin banyak pemanfaatan SIA dalam suatu Instansi dapat meningkatkan kualitas laporan keuangan pemerintah daerah. Sebaliknya semakin rendah pemanfaatan SIA dalam suatu Instansi dapat menyebabkan kualitas laporan keuangan pemerintah daerah semakin menurun. Teori stewardship menyatakan bahwa pemerintah sebagai good steward harus dapat menyajikan informasi yang akurat kepada principal secara tepat waktu. Maka upaya yang akan dilakukan pemerintah untuk menyajikan informasi yang bermanfaat dan laporan keuangan yang berkualitas adalah dengan memanfaatkan SIA untuk menunjang aktivitas pemerintah. Melalui pemanfaatan sistem yang sudah terintergrasi di Instansi pemerintah dapat mendukung untuk menghasilkan laporan keuangan yang berkualitas (Khairudin, 2017). Hasil penelitian ini diperkuat oleh penelitian Yuliani (2010), Silviana (2014), Purwanti (2014), Armel (2017), Fitriana (2017), Pujanira (2017), dan bertentangan dengan penelitian Anggraeni (2014), Diani (2014), Pramudiarta (2015) dan Riandani (2017).

\section{Pengaruh kompetensi SDM sebagai Variabel moderasi terhadap Hubungan antara Pemahaman} SAP dengan Kualitas Laporan Keuangan Pemerintah Daerah

Kompetensi SDM memoderasi (memperkuat) hubungan antara pemahaman SAP dengan kualitas laporan keuangan pemerintah daerah. Pemahaman SAP akan meningkatkan kualitas laporan keuangan pemerintah daerah pada saat tingkat kompetensi SDM tinggi, sebaliknya pemahaman SAP akan menurunkan kualitas laporan keuangan pemerintah daerah pada saat tingkat kompetensi SDM rendah. Teori stewardship yang menjelaskan bahwa adanya kompetensi SDM dapat mendukung tercapainya tujuan organsiasi. Salah satu tujuan organisasi pemerintah adalah menghasilkan laporan keuangan yang berkualitas. Oleh karena itu perlu adanya keterlibatan SDM yang memiliki kompetensi untuk dapat menciptakan laporan keuangan yang berkualitas. Sebab yang menyusun dan menyajikan laporan keuangan adalah SDM itu sendiri. Jika kompetensi yang dimiliki SDM tinggi, maka pemahaman mengenai akuntansi pemerintah dan SAP semakin baik sehingga dapat menghasilkan laporan keuangan yang berkualitas (Hardyansah, 2016). Hasil penelitian ini diperkuat oleh Wati (2014) dan Rafid (2016) , dan bertentangan dengan penelitian Inapty dan Martiningsih (2016).

\section{Pengaruh kompetensi SDM sebagai Variabel moderasi terhadap Hubungan antara Pemanfaatan SIA dengan Kualitas Laporan Keuangan Pemerintah Daerah}

Kompetensi SDM memoderasi (memperkuat) hubungan antara Pemanfaatan SIA dengan kualitas laporan keuangan pemerintah daerah. Pemanfaatan SIA akan menurunkan kualitas laporan keuangan pemerintah daerah pada saat tingkat kompetensi SDM tinggi, sebaliknya Pemanfaatan SIA akan meningkatkan kualitas laporan keuangan pemerintah daerah pada saat tingkat kompetensi 
Debby Christin Sihasale, Pengaruh Pemahaman Standar Akuntansi Pemerintah Dan Pemanfaatan Sistem Informasi Akuntansi Terhadap Kualitas Laporan Keuangan Pemerintah Daerah Dengan Kompetensi SDM Sebagai Variabel Moderasi SDM rendah. Teori stewardhip memiliki pandangaan bahwa SDM yang memiliki kompetensi dapat mendukung terwujudnya tujuan orgasnisasi. Laporan keuangan dapat berkualitas apabila disusun oleh SDM yang berkompetensi. Kompetensi SDM akan mendukung SDM dalam memanfaatkan SIA untuk dapat menyajikan laporan keuangan yang berkualitas sehingga informasi yang nantinya dihasilkan dapat bermanfaat bagi para pengguna laporan keuangan (Hardyansah, 2016). Hasil penelitian ini diperkuat oleh Sugara (2015), Agustiawan (2016), Rafid (2016) dan khairudin (2017), dan bertentangan dengan penelitian Muda (2017).

\section{KESIMPULAN DAN SARAN}

\section{Kesimpulan}

Penelitian ini menyimpulkan bahwa pemahaman SAP berpengaruh terhadap kualitas laporan keuangan pemerintah daerah, pemanfaatan SIA berpengaruh terhadap kualitas laporan keuangan pemerintah daerah, Kompetensi SDM memoderasi (memperkuat) hubungan antara pemahaman SAP dengan kualitas laporan keuangan pemerintah daerah, serta Kompetensi SDM memoderasi (memperkuat) hubungan antara pemanfaatan SIA dengan kualitas laporan keuangan pemerintah daerah.

\section{Saran}

Pemerintah harus berupaya untuk meningkatkan kompetensi SDM dan meningkatkan kualitas laporan keuangan pemerintah daerah dengan cara lebih meningkatkan pemahaman mengenai SAP dan memanfaatkan sistem yang terintergrasi di Intansi pemerintah. selain itu pegawai-pegawainya diharapkan untuk mengikuti setiap pelatihan-pelatihan atau diklat untuk menunjang kompetensinya sehingga dapat memudahkannya untuk menyusun laporan keuangan yang baik dan benar.

Peneliti selanjutnya sebaiknya menggunakan sampel penelitian yang lebih besar dan variatif, memperpanjang rentang waktu pengamatan dan menggunakan data yang lebih spesifik agar hasil penelitian lebih lengkap dan akurat, menambahkan variabel independen lain yang dapat mempengaruhi nilai perusahaan seperti sistem pengendalian internal dan peran audit, serta menggunakan variabel moderating lain seperti komitmen organisasi.

\section{DAFTAR PUSTAKA}

Arfianti, Dita. 2011. Analisis Faktor-faktor Yang Mempengaruhi Kualitas Laporan Keuangan Pemerintah Daerah (Studi Pada Satuan Kerja Perangkat Daerah Di Kabupaten Batang). Skripsi. Semarang: Universitas Di Penogoro.

Armel, Raja Yoga Gustika. 2017. Pengaruh Kompetensi Sumber Daya Manusia, Penerapan Standar Akuntansi Pemerintah, Pemanfaatan Teknologi Informasi Dan Sistem Pengendalian Internal Terhadap Kualitas Laporan Keuangan Pemerintah Daerah. Jom Fekom. 4 (1): 1-15

Artana, Arlia Sari. 2016. Pengaruh Pemahaman Standar Akuntansi Pemerintah Dan Pemanfataan Sistem Informasi Akuntansi Keuangan Daerah Dan Sistem Pengendalian Internal Terhadap Kualitas Laporan Keuangan Pemerintah Daerah. Skripsi. Jakarta: Universitas Islam Negeri Syarif Hidayatullah.

Darwanis, Arfan Muhammad dan Iqlima A. Manaf. 2016. The Effect of Understanding of Government Accounting Standard and Internal Control System on Quality of Finacial Statement from Local Government through Review Process of Financial Statement by Inspectorate Agency (A Study at 
Debby Christin Sihasale, Pengaruh Pemahaman Standar Akuntansi Pemerintah Dan Pemanfaatan Sistem Informasi Akuntansi Terhadap Kualitas Laporan Keuangan Pemerintah Daerah Dengan Kompetensi SDM Sebagai Variabel Moderasi

Inspectorate Agencies in the Regencies and Cities of the Province of Aceh, Indonesia). Research journal of finance and accounting. 7 (4): 1-8.

Diani, Dian Irma. 2014. Pengaruh Pemahaman Akuntansi, Pemanfaatan Sistem Informasi Akuntansi Keuangan Daerah Dan Peran Internal Audit Terhadap Kualitas Laporan Keuangan Pemerintah Daerah. Artikel Ilmiah. Padang: Universitas Negeri Padang.

Fitriana dan Agus Wahyudin. 2017. Factors Influencing The Quality Of Financial Reporting On Local Government Of Purbalingga. Accounting Analysis Journal. 6 (1): 1-12

Ghozali, Imam. 2009. Aplikasi Analisis Multivariat dengan Program SPSS. Semarang: Badan Penerbit Universitas Diponegoro.

Hardyansah. 2016. Pengaruh Kompetensi Sumber Daya Manusia Dan Pemanfaatan Teknologi Informasi Terhadap Kualitas Laporan Keuangan Dengan Sistem Pengendalian Intern Sebagai Variabel Moderating. Skripsi. Makasar: Universitas Islam Negeri Alauddin.

Hanaffi, Ranny. 2017. Faktor-faktor Yang Mempengaruhi Kualitas Laporan Keuangan Pemerintah Daerah. Skripsi. Surakarta: Institut Agama Islam Negeri Surakarta.

Khairudin, Ibnu. 2017. Pengaruh Pemahaman Sistem Akuntansi Keuangan Daerah Dan Pemanfaatan Teknologi Informasi Terhadap Kualitas Laporan Keuangan Daerah Dengan Kompetensi Sumber Daya Manusia Sebagai Variabel Moderasi. Artikel Ilmiah. Yogyakarta: Universitas Muhammadiyah.

Mardiasmo, 2009. Akuntansi Sektor Publik. Yogyakarta: Penerbit Salemba Empat

Muda, Iskandar. Deni Y Wardani. Erliana. Azhar Maksum dkk. 2017. The Influence Of Human Resources Competency And The Use Of Information Technology On The Quality Of Local Government Financial Report With Regional Accounting System As An Intervening. Journal of Theoretical And Applied Information Technology. 95 (20): 1-10

Nugraheni, Purwaniati dan Imam Subaweh, 2013. Pengaruh Penerapan Standar Akuntansi Pemerintahan Terhadap Kualitas Laporan Keuangan. Jurnal Ekonomi Bisnis, 13 (1): 1-10.

Nurillah, As Syifa. 2014. Pengaruh Kompetensi Sumber Daya Manusia, Penerapan Sistem Akuntansi Keuangan Daerah (SAKD), Pemanfaatan Teknologi Informasi Dan Sistem Pengendalian Intern Terhadap Kualitas Laporan Keuangan Pemerintah Daerah. Skrispsi. Semarang: Universitas Di Penogoro

Nuryanto, Muhamad. Dan Nunuy Nur Afiah. 2013. The Impact of Apparatus Competence, Information Technology Utilization and Internal Control on Financial Statement Quality (Study on Local Government of Jakarta Province - Indonesia). World review of Business Research, 3(4):1-14.

Pujanira, Putriasri dan Abdullah Taman. 2017. Pengaruh Kompetensi Sumber Daya Manusia, Penerapan Standar Akuntansi Pemerintah Dan Penerapan Sistem Akuntansi Keuangan Daerah Terhadap Kualitas Laporan Keuangan Pemerintah Daerah Provinsi DIY. Jurnal Nominal. 6 (2): 1-14

Purwanti, Meilani dan Wasman. 2014. Pengaruh Pemahaman Akuntansi,Pemanfaatan Sistem Informasi Akuntansi Dan Peran Internal Audit Terhadap Kualitas Laporan Keuangan. Jurnal Bisnis Dan Manajemen. 4 (3): 1-15

Pramudiarta, Rizal. 2015. Pengaruh Kompetensi Sumber Daya Manusia, Pemanfaatan Teknologi Informasi Dan Sistem Pengendalian Intern Terhadap Nilai Informasi Pelaporan Keuangan Entitas Akuntansi Pemerintah Daerah. Skripsi. Semarang: Universitas Dipenogoro. 
Debby Christin Sihasale, Pengaruh Pemahaman Standar Akuntansi Pemerintah Dan Pemanfaatan Sistem Informasi Akuntansi Terhadap Kualitas Laporan Keuangan Pemerintah Daerah Dengan Kompetensi SDM Sebagai Variabel Moderasi

Rafid, Rashwan Zuhudy. 2016. Pengaruh Pemahaman Standar Akuntansi Pemerintah Dan Pemanfaatan Sistem Informasi Akuntansi Terhadap Kualitas Laporan Keuangan Dengan Kompetensi Sumber Daya Manusia Sebagai Variabel Moderasi. Skripsi. Makasar: Universitas Islam Negeri Alauddin

Riandani, Riedy. 2017. Pengaruh Kompetensi Sumber Daya Manusia, Pemanfaatan Teknologi Informasi Dan Pengendalian Intern Terhadap Kualitas Laporan Keuangan. Artikel Ilmiah. Padang: Universitas Negeri Padang

Rianisanti, Meta Dewi. 2017. Pemanfaatan Sistem Informasi Akuntansi Keuangan Daerah Dan Kapasistas Sumber Daya Manusia Terhadap Kualitas Laporan Keuangan Pemerintah Daerah Dengan Sistem Pengendalian Intern Sebagai Variabel Moderating. Skripsi. Surakarta: Institut Agama Islam Negeri Surakarta.

Sanjaya, Aditya. M. Rasuli dan Eka Haryani. 2017. Pengaruh Penerapan Standar Akuntansi Pemerintah, Sistem Pengendalian Intern, Sistem Akuntansi Keuangan Daerah Dan Sumber Daya Manusia Terhadap Kualitas Laporan Keuangan Pemerintah Daerah Dengan Komitmen Organisasi Sebagai Pemoderasi. JOM Fekon. 4 (1): 1-15

Sari, Ni Putu Yogi Merta Maeka, I Made Pradana Adiputra dan Edy Sujana. 2014.

Pengaruh Pemahaman Standar Akuntansi Pemerintah (SAP) Dan Pemanfaatan Sistem Informasi Akuntansi Keuangan Daerah Terhadap Kualitas Laporan Keuangan Pemerinta Daerah. E-journal S1 Ak Universitas Pendidikan Ganesha. 2 (1): 1-12

Silviana dan Antoni Erwin. 2014. Pengaruh Penerapan Sistem Informasi Akuntansi Terhadap Kualitas Laporan Kuangan Pemerintah Daerah Survey Pada Pemerintah Kabupaten Di Seluruh Jawa Barat. Profita. 6 (1): 1-13.

Sugara, Yusar. 2015. The Effect Of Implementation Accounting Information System And Competence Of Human Resourses On The Quality Of Financial Reporting. Reseacrh Journal Of Finance And Accounting. 6 (10): 1-6

Sugiyono. 2011. Metode Penelitian Kuantitatif, Kualitatif, dan R \& D. Bandung: Alfabeta.

Suliyantini, Liani dan Kusmuriyanto. 2017. The Effect Of Human Resources Competency And Accrual Based Government Accounting Standard Implementation Of Internal Control System As a Mediating Variable. Accounting Analysis Journal. 6 (1): 1-8

Wati, Kadek Desiana, Nyoman Trisna Herawati dan Ni Kadek Sinarwati. 2014. Pengaruh Kompetensi SDM, Penerapan SAP, Dan Sistem Akuntansi Keuangan Daerah Terhadap Kualitas Laporan Keuangan Daerah. E-journal S1 Ak Universitas Pendidikan Ganesha. 2 (1): 1-11

Wijayanti, Ratna dan Nur Handayani. 2017. Pengaruh Kompetensi SDM Dan Impelementasi Akuntansi Akrual Terhadap Kualitas Laporan Keuangan Daerah. Jurnal Ilmu dan Riset Akuntansi. 6(3): 1-18

Yuliani, Safrida, Nadirsyah dan Usman Bakar. Pengaruh Pemahaman Akuntansi, Pemanfaatan Sistem Informasi Akuntansi Keuangan Daerah Dan Peran Internal Audit Terhadap Kualitas Laporan Keuangan Pemerintah Daerah. Jurnal Telaah \& Riset Akuntansi. 3 (2): 1-14 